\title{
A Response Surface Methodology study on the role of factors affecting growth and volatile phenol production by Brettanomyces bruxellensis ISA 2211 in wine
}

\author{
M. Chandra ${ }^{\text {a,* }}$, A. Barata ${ }^{\text {a }}$, S. Ferreira-Dias ${ }^{\text {b }}$, M. Malfeito-Ferreira ${ }^{a}$, V. Loureiro ${ }^{a}$ \\ ${ }^{a}$ Laboratório de Microbiologia, Centro de Botânica Aplicada à Agricultura (CBAA), Instituto Superior de Agronomia, University of Lisbon, Tapada da Ajuda, \\ 1349-017 Lisboa, Portugal \\ ${ }^{\mathrm{b}}$ Centro de Engenharia dos Biossistemas (CEER), Instituto Superior de Agronomia, University of Lisbon, Tapada da Ajuda, 1349-017 Lisboa, Portugal
}

\section{A R T I C L E I N F O}

\section{Article history:}

Received 14 June 2013

Received in revised form

20 February 2014

Accepted 3 March 2014

Available online 13 March 2014

\section{Keywords:}

Wine

Spoilage yeasts

Brettanomyces bruxellensis

4-Ethylphenol

Response Surface Methodology

\begin{abstract}
A B S T R A C T
The present study was aimed at determining the effect of glucose, ethanol and sulphur dioxide on the growth and volatile phenol production by Brettanomyces bruxellensis in red wines using a response surface methodology approach. Sulphur dioxide proved to have a significant $(p<0.05)$ negative linear and quadratic effect on growth and 4-ethylphenol production. Concentrations of sulphur dioxide higher than $20 \mathrm{mg} \mathrm{L}^{-1}$, at $\mathrm{pH} 3.50$, induced immediate loss of cell culturability under growth permissive levels of ethanol. Under high ethanol concentrations $(14 \% \mathrm{v} / \mathrm{v})$, the lag phase increased from 3 to 10 days, growth being fully arrested at $15 \%(\mathrm{v} / \mathrm{v})$. Glucose up to $10 \mathrm{~g} \mathrm{~L}^{-1}$ was found to be a significant factor (quadratic level) in biomass increase under low ethanol $(<12.5 \% \mathrm{v} / \mathrm{v})$ and low sulphite concentrations. However, when cells were inactivated by sulphur dioxide and ethanol, glucose (up to $10 \mathrm{~g} \mathrm{~L}^{-1}$ ) did not prevent cell death. Production of more than $50 \mu \mathrm{g} \mathrm{L}^{-1} \mathrm{day}^{-1}$ of 4-ethylphenol was only observed in the presence of high numbers $\left(10^{6} \mathrm{CFU} \mathrm{mL}^{-1}\right)$ of culturable cells, being stimulated by increasing glucose concentrations.
\end{abstract}

(c) 2014 Elsevier Ltd. All rights reserved.

\section{Introduction}

The growth of the yeast species Brettanomyces bruxellensis in wine has been associated with various forms of spoilage including cloudiness and a range of off-flavours (Malfeito-Ferreira, 2011). The production of volatile phenols is the most important feature of wine spoilage during winemaking and has been well documented (Chatonnet et al., 1992, 1995; Egli et al., 1998; Malfeito-Ferreira, 2011; Suárez et al., 2007). Among these, 4-ethylphenol (4-EP) is responsible for "horse-sweat" off-odours that are detrimental to the aroma profile of red wines at concentrations higher than the preference threshold (Chatonnet et al., 1995; Suárez et al., 2007). However, conditions which affect their production in wine and the exact mechanisms involved are not fully understood.

Some of the wine factors/constituents (e.g. sulphur dioxide, ethanol, $\mathrm{pH}$, sugar and oxygen concentration) are reported to play a key role on cell growth and, consequently, on 4-ethylphenol production (Barata et al., 2008; Ciani et al., 2003). Sulphur dioxide is the main preservative used in wines and Dekkera bruxellensis has

\footnotetext{
* Corresponding author. Tel.: +351 21365 3242; fax: +351 213653383 .

E-mail address: mchandra@isa.utl.pt (M. Chandra).
}

been regarded as either resistant or sensitive (Loureiro and Malfeito-Ferreira, 2006). Some authors refer its sensitivity to free sulphite higher than $30 \mathrm{mg} \mathrm{L}^{-1}$ (Chatonnet et al., 1992; Gerbaux et al., 2002), explaining its frequent isolation from sulphur dioxide unprotected wines (Heresztyn, 1986). On the other hand, others have reported its survival under more than $30 \mathrm{mg} \mathrm{L}^{-1}$ of free sulphite (Froudière and Larue, 1988), though recent reports show sensitivity and resistance to $\mathrm{SO}_{2}$ to be a strain specific character (Conterno et al., 2006; Vigentini et al., 2013). Our previous results pointed out that ethanol is a major factor determining sulphite resistance (Malfeito-Ferreira et al., 2004). Some authors reported the high conversion rate of $p$-coumaric acid into 4-EP in presence of ethanol and glucose (Benito et al., 2009; Dias et al., 2003). However, according to others, there is no relation between 4-EP production and glucose consumption (Coulon et al., 2010). The reason for these conflicting results may be due to the diversity of conditions under study. Therefore, it would be helpful to have a strategy where several factors could be tested simultaneously. In particular, glucose effect is of importance to establish as winemakers tend to use residual levels in order to obtain red wines with softer mouthfeel. Thus, in order to understand the interaction among three main factors (sulphur dioxide, sugar and ethanol), a Response Surface Methodology (RSM) was chosen for modelling growth and 4-EP 
production. With RSM, several variables may be tested simultaneously with a minimum number of experiments, according to special experimental designs, which enables to find interactions between variables (Gacula and Singh, 1984; Montgomery, 1991).

\section{Material and methods}

\subsection{Yeast strain and maintenance}

The strain B. bruxellensis ISA 2211 was isolated in our laboratory from a phenolic tainted red wine and was chosen because of its tolerance to $15 \%$ (v/v) ethanol (Barata et al., 2008). It was maintained in slants of GYP medium $\left(20 \mathrm{~g} \mathrm{~L}^{-1}\right.$ glucose (Merck, Darmstadt, Germany), $5 \mathrm{~g} \mathrm{~L}^{-1}$ yeast extract (Difco Laboratories, Detroit, USA), $10 \mathrm{~g} \mathrm{~L}^{-1}$ peptone (Difco) $\mathrm{pH} 6.0$ ) at $4{ }^{\circ} \mathrm{C}$.

\subsection{Culture conditions}

B. bruxellensis ISA 2211 inoculum was prepared by growth in $100 \mathrm{~mL}$ of Yeast Nitrogen Broth $\left(6.7 \mathrm{~g} \mathrm{~L}^{-1}\right.$ YNB with $10 \%$ ethanol), adjusted to $\mathrm{pH} 3.50 \pm 0.01$, sterilized by membrane filtration $\left(0.22 \mu \mathrm{m}\right.$ pore size) and incubated at $25{ }^{\circ} \mathrm{C}$ with orbital shaking (120 rpm). Growth was followed by measuring the absorbance at $640 \mathrm{~nm}$. When about 0.5 units were reached, wines were inoculated to give an initial population of about $10^{5}$ cells $\mathrm{mL}^{-1}$. Wines were incubated at $25^{\circ} \mathrm{C}$ in $100 \mathrm{~mL}$ Erlenmeyer flasks capped with rubber plugs with inserted hypodermic needles with a minimal amount of headspace. Cell numbers were counted at different time intervals using surface agar plating onto GYP.

Experimental wines were obtained from a blend of several commercial red wines without residual sugar $\left(<2 \mathrm{~g} \mathrm{~L}^{-1}\right)$. The sulphur dioxide concentration was adjusted using potassium metabisulphite or removed using acetaldehyde (Ribéreau-Gayon et al., 2006). The ethanol content was adjusted to different concentrations with a solution of $5 \mathrm{~g} \mathrm{~L}^{-1}$ of tartaric acid (Merck) or $99 \%$ pure ethanol (Merck). The total polyphenol index (TPI) was ascertained to be 54.3 by addition of ellagic tannin (Tanisouple, AEB group) in wine. The $\mathrm{pH}$ value was adjusted to 3.50 with concentrated $\mathrm{NaOH}$ (Merck) or $\mathrm{HCl}$ (Merck). The final wine blends were sterilized by filtration through cellulose acetate membranes $(0.22 \mu \mathrm{m}$ pore size and $47 \mathrm{~mm}$ diameter, Millipore).

\subsection{Chemical analysis}

\subsubsection{Conventional analysis}

Ethanol content, $\mathrm{pH}$, density, total and volatile acidities, and free and total sulphur dioxide were measured according to Organisation International de la Vigne et du Vin methods (OIV) (2006). Total polyphenol index (TPI) was determined by following the method described of Ribéreau-Gayon et al. (1998). Colour intensity, hue and brilliance of wine were measured and calculated according to the protocols described in OIV (1990) and Blouin (1992). Colour intensity was calculated as the sum of absorbance at 420, 520 and $620 \mathrm{~nm}$. The tint or hue of a wine was calculated as the ratio $A_{420} /$ $A_{520}$, which gives a measure of the "tint" or redness of the wine. The brilliance of a wine was calculated by the expression:

$d A(\%)=\left(1-\left(A_{420}+A_{620} / 2 A_{520}\right)\right) \times 100$

\subsubsection{Instrumental analysis}

The concentrations of sugars, organic acids and alcohols were assessed by high performance liquid chromatography (HPLC). Frozen samples were centrifuged for $10 \mathrm{~min}$ and the supernatant $(1 \mathrm{~mL})$ was deproteinized by adding $34.5 \mu \mathrm{L}$ perchloric acid $(60 \% \mathrm{p} /$ v) (Merck). The samples were kept on ice during $30 \mathrm{~min}$ and centrifuged followed by filtration by a membrane of $0.22 \mathrm{~mm}$ pore size (Millipore). An amount of $20 \mu \mathrm{L}$ was used for injection for HPLC (Waters 501), at a flow rate of $0.6 \mathrm{~mL} \mathrm{~min}^{-1}$ of a solution of $2.5 \mathrm{mM}$ $\mathrm{H}_{2} \mathrm{SO}_{4}$ (mobile phase). The separation was performed in a sizeexclusion and ion-exchange column $(8.0 \times 300 \mathrm{~mm}$, Shodex SH1011) at $60{ }^{\circ} \mathrm{C}$. The compounds were quantified in a refractive index detector (Waters 2410) and the integration was done using the chromatography data software Empower-2 (Waters, USA).

The 4-EP production was measured according to a protocol described by Bertrand (1981). Briefly, the volatile phenol was extracted by ether-hexan from a $5 \mathrm{~mL}$ sample with $\mathrm{pH}$ adjusted to 8.0 with $\mathrm{NaOH}$. The 4-ethylphenol was separated by collecting the organic phase of the mixture. The quantification was achieved by gas chromatography using 3,4-dimethylphenol as internal standard. A GC-FID (Varian CP-3800) series with a capillary column from Factor Four (ID $0.25 \mathrm{~mm}$, length $15 \mathrm{~m}$, film thickness $0.25 \mu \mathrm{m}$ ) was used. The injector was run in splitless mode, at $230{ }^{\circ} \mathrm{C}$ and the volume of $2 \mu \mathrm{L}$ was used in injection. The detector temperature was set to $250{ }^{\circ} \mathrm{C}$. Hydrogen was used as carrier gas at a flow of $0.1 \mathrm{~mL} \mathrm{~min}^{-1}$. The oven was initially set at $50^{\circ} \mathrm{C}$, raised to $215^{\circ} \mathrm{C}$ at $10{ }^{\circ} \mathrm{C} \mathrm{min}{ }^{-1}$ and finally up to $250^{\circ} \mathrm{C}$ at a rate of $20^{\circ} \mathrm{C} \mathrm{min}{ }^{-1}$.

\subsection{Response Surface Methodology}

\subsubsection{Experimental design}

In Response Surface Methodology (RSM), the response $y$ is described by a polynomial equation as a function of the $p$ independent variables, $x_{i}$, that is,

$Y=f\left(x_{1}, x_{2}, \ldots, x_{p}\right)+\varepsilon$

where $\varepsilon$ represents the error observed in the response $y$. Usually the response is well modelled by a first or a second-order polynomial representing a $(p+1)$ dimensional surface, i.e., the response surface (Gacula and Singh, 1984). The parameters of these equations are usually unknown and, therefore, must be estimated from the experimental data by using the statistical principle of least squares. In second-order equations, the coefficients of the squared terms influence the direction of the curvature of the response surfaces. In the present study, the influence of three factors (variables) viz., sugar, ethanol and sulphur dioxide, was studied using a central composite rotatable design (CCRD). It consists of the following three sets of experimental points:

1. A factorial design with $2 p$ data-points (extremes), which represent the vertices of a $p$-dimensional cube, at a distance of $p^{1 / 2}$ from the origin of the coded system of reference. In the coded matrix, they correspond to the levels $(-1)$ and $(+1)$ for each variable (Table 1$)$.

2. A group of $2 p$ points on the axes of the system of reference, outside of the factorial matrix, but inside the experimental domain, at a distance equal to $2^{p / 4}$ from the origin (star-points). These levels correspond to -1.68 and 1.68 (Table 1 ).

3. A third set composed by the repetition of the points at the origin of the reference system (centre-points), coded as $(0,0)$.

The set of 17 experiment CCRD was designed to understand the interaction of sulphur dioxide, ethanol and glucose using realistic concentrations of each parameter in wines, as follows: sulphur dioxide varied from 0 to $40 \mathrm{mg} \mathrm{L}^{-1}$, ethanol levels ranged from 10 to $15 \%(\mathrm{v} / \mathrm{v})$ and glucose varied from 2 to $10 \mathrm{~g} \mathrm{~L}^{-1}$ (Table 1$)$. These ranges were selected based on previous experiments where both cell growth and no growth was observed. 
Table 1

Coded matrix of CCRD experimental design.

\begin{tabular}{lccccccc}
\hline \multirow{2}{*}{ Experiment } & Variable & & & & \multicolumn{3}{l}{ Concentrations } \\
\cline { 2 - 4 } \cline { 6 - 7 } & Glucose & Ethanol & $\mathrm{SO}_{2}$ & & $\begin{array}{l}\text { Glucose } \\
\left(\mathrm{g} \mathrm{L}^{-1}\right)\end{array}$ & $\begin{array}{l}\text { Ethanol \% } \\
(\mathrm{v} / \mathrm{v})\end{array}$ & $\begin{array}{l}\mathrm{SO}_{2} \\
\left(\mathrm{mg} \mathrm{L}^{-1}\right)\end{array}$ \\
\hline 1 & -1 & -1 & -1 & 3.6 & 11.0 & 8 \\
2 & 1 & -1 & -1 & 8.4 & 11.0 & 8 \\
3 & -1 & 1 & -1 & 3.6 & 14.0 & 8 \\
4 & 1 & 1 & -1 & 8.4 & 14.0 & 8 \\
5 & -1 & -1 & 1 & 3.6 & 11.0 & 32 \\
6 & 1 & -1 & 1 & 8.4 & 11.0 & 32 \\
7 & -1 & 1 & 1 & 3.6 & 14.0 & 32 \\
8 & 1 & 1 & 1 & 8.4 & 14.0 & 32 \\
9 & -1.68 & 0 & 0 & 2 & 12.5 & 20 \\
10 & 1.68 & 0 & 0 & 10 & 12.5 & 20 \\
11 & 0 & -1.68 & 0 & 6 & 10 & 20 \\
12 & 0 & 1.68 & 0 & 6 & 15 & 20 \\
13 & 0 & 0 & -1.68 & 6 & 12.5 & 0 \\
14 & 0 & 0 & 1.68 & 6 & 12.5 & 40 \\
$15(\mathrm{C})$ & 0 & 0 & 0 & 6 & 12.5 & 20 \\
$16(\mathrm{C})$ & 0 & 0 & 0 & 6 & 12.5 & 20 \\
17 (C) & 0 & 0 & 0 & 6 & 12.5 & 20 \\
\hline
\end{tabular}

\subsubsection{Statistical analysis}

The results of the 17 experiments of each CCRD were analysed using the software "Statistica" ${ }^{\mathrm{TM}}$ " version 7 (Statsoft, USA). The linear and quadratic effects were calculated and their significance was evaluated by analysis of variance. A four-dimensional surface, described by a first- or a second-order polynomial equation was fitted to each set of experimental data points. First- and secondorder coefficients were generated by regression analysis. The fit of the models was evaluated by the determination coefficients $\left(R^{2}\right)$ and adjusted $R^{2}\left(R_{\mathrm{adj}}^{2}\right)$ (Weisberg, 1985).

\section{Results and discussion}

Preliminary CCRD experiments were conducted to determine the concentration range of inhibitors and incubation times. In two of the CCRD sets, low ethanol (ranging from 8 to 15\% v/v) and sulphite concentrations (ranging from 0 to $8 \mathrm{mg} \mathrm{L}^{-1}$ ) resulted in cell growth in most of experiments of both CCRD sets. As a result, no appropriate model could be designed (results not shown), therefore sulphur dioxide concentration ranging from 0 to $40 \mathrm{mg} \mathrm{L}^{-1}$, and ethanol ranging from 10 to $15 \%(\mathrm{v} / \mathrm{v})$ were selected to search out the suitable model. Regarding incubation time, prolonged incubation periods were used in order to model the growth response after the period where viable cells were not detected (Fig. 1).
The experimental results of all seventeen experiments of the selected CCRD set are shown in Table 2. The linear and quadratic effects of the factors, as well as their linear interactions, on cell growth and on 4-EP production are presented in Table 3 for several days of incubation. Four-dimensional surfaces, described by second-order polynomial equations as a function of the factors with significant effect on the response, or of those with effects important enough not be neglected were fitted to the experimental data points (growth and 4-EP production). The high values of both $R^{2}$ and $R^{2}$ adj indicated a good fit of the models to experimental results (Table 4).

Since we obtained a four-dimensional response as a function of three factors, the response surfaces must be represented in two 3dimensional surfaces as a function of two factors keeping the third one constant and with the value of the centre (e.g. sulphur dioxide, $20 \mathrm{mg} \mathrm{L}^{-1}$; glucose, $6 \mathrm{~g} \mathrm{~L}^{-1}$; ethanol, $\left.12.5 \% \mathrm{v} / \mathrm{v}\right)$. The response surface plots of the cell growth at day 2 and day 30 as a function of sulphur dioxide, ethanol and glucose are shown in Figs. 2 and 3, respectively. Sulphur dioxide was the single factor showing a significant negative effect on day 2 , responsible for immediate death phase as illustrated by the shape of the two curves in Fig. 2. A similar response on growth was observed as a function of sulphur dioxide concentration at day 5 (results not shown). At day 30, a positive effect of sulphur dioxide at quadratic level was reflected by the concave response surface (Fig. 3). In should be noted that free sulphite was found to be null on 30th day of observation (Supplementary Fig. 1), therefore inhibitory effect of sulphite if observed on day 30 , is only due to sulphite inhibition in the earlier days of incubation. On this time, in the experiments where cell growth was observed glucose was already consumed (results not shown) and so the glucose effect also appears to be negligible after 30 days of incubation. However, the effect of ethanol was slightly inhibitory as illustrated by the slight inclination of the surface (Fig. 3).

The shape of the surfaces obtained for the 4-EP production after 30 days of incubation reflected the predominant inhibition (linear and quadratic effects) by sulphite which can be explained by its role on cell death and consequent absence of 4-EP production (Fig. 4). Interestingly, ethanol also exerted an inhibitory interaction with sulphur dioxide for the production of 4-EP, as shown in the model equation (see Table 4).

Overall, in experiments of initial sulphur dioxide exposure above $20 \mathrm{mg} \mathrm{L}^{-1}$, cells showed sharp death not recovering growth. At $20 \mathrm{mg} \mathrm{L}^{-1}$, or below, cells initially showed a steep loss of culturability to values less than the detection threshold of $10 \mathrm{CFU} \mathrm{mL} \mathrm{m}^{-1}$ (Table 2). After a variable gap, from few to more than 15 days, culturability was reassumed in some experiments (Table 2 and

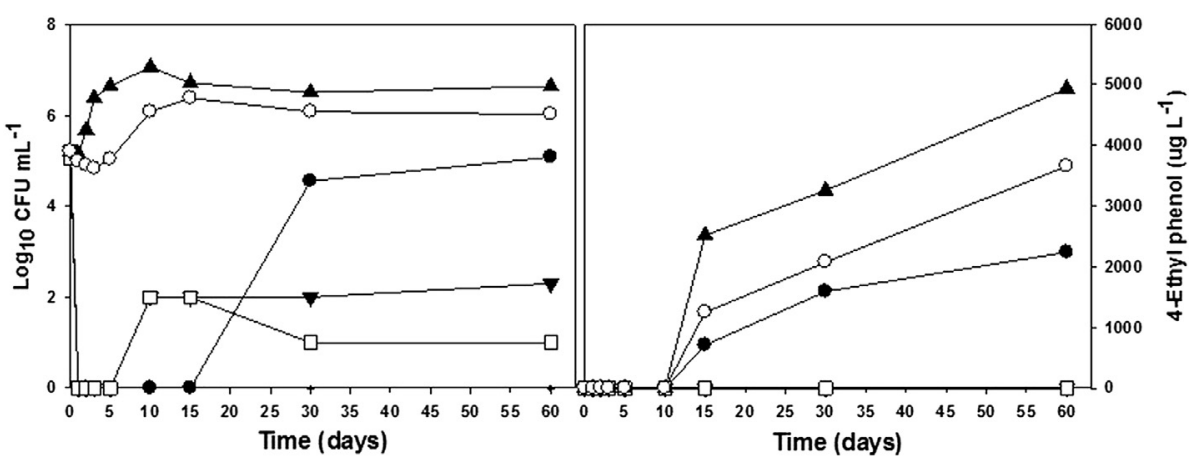

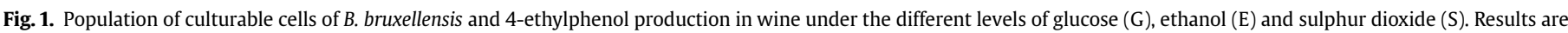

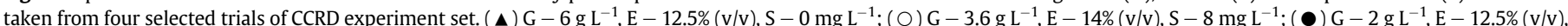

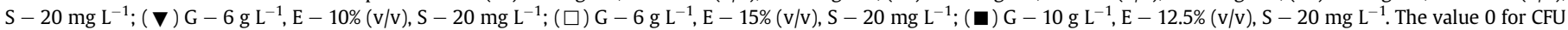
counts indicates the absence of colonies in the volume of $0.1 \mathrm{ml}$ of wine sample. 
Table 2

B. bruxellensis cell growth and 4-ethylphenol production as a function of glucose, ethanol and sulphur dioxide concentrations.

\begin{tabular}{|c|c|c|c|c|c|c|c|c|c|c|c|c|c|c|}
\hline \multirow[t]{2}{*}{ Experiment } & \multicolumn{9}{|c|}{$\log \mathrm{CFU} \mathrm{mL}^{-1}$} & \multirow{2}{*}{$\begin{array}{l}\text { Days to achieve one } \\
\text { log increase }\end{array}$} & \multicolumn{4}{|c|}{ 4-Ethylphenol $\left(\mu \mathrm{g} \mathrm{L}^{-1}\right)$} \\
\hline & D0 & D1 & D2 & D3 & D5 & D10 & D15 & D30 & D60 & & D15 & D30 & D60 & $\begin{array}{l}\text { Production rate } \\
(\Delta 4-\mathrm{EP} / \text { day })\end{array}$ \\
\hline 1 & 5.24 & 5.16 & 6.38 & 6.68 & 5.86 & 5.90 & 6.20 & 6.56 & 5.64 & 3 & 1166 & 1487 & 2766 & 46 \\
\hline 2 & 5.18 & 5.21 & 6.38 & 5.81 & 6.16 & 7.02 & 5.90 & 6.38 & 5.70 & 3 & 1334 & 1604 & 3086 & 51 \\
\hline 3 & 5.20 & 4.99 & 4.90 & 4.83 & 5.03 & 6.08 & 6.38 & 6.08 & 6.02 & 10 & 1247 & 2077 & 3656 & 61 \\
\hline 4 & 5.17 & 4.60 & 4.90 & 4.75 & 5.64 & 6.08 & 6.78 & 5.86 & 6.03 & 10 & 1648 & 2526 & 3931 & 66 \\
\hline 5 & 5.23 & $<1.00$ & $<1.00$ & $<1.00$ & $<1.00$ & $<1.00$ & $<1.00$ & $<1.00$ & $<1.00$ & - & $\mathrm{nd}^{\mathrm{a}}$ & nd & nd & - \\
\hline 6 & 5.19 & $<1.00$ & $<1.00$ & $<1.00$ & $<1.00$ & $<1.00$ & $<1.00$ & $<1.00$ & $<1.00$ & - & nd & nd & nd & - \\
\hline 7 & 5.18 & $<1.00$ & $<1.00$ & $<1.00$ & $<1.00$ & $<1.00$ & $<1.00$ & $<1.00$ & $<1.00$ & - & nd & nd & nd & - \\
\hline 8 & 5.25 & $<1.00$ & $<1.00$ & $<1.00$ & $<1.00$ & $<1.00$ & $<1.00$ & $<1.00$ & $<1.00$ & - & nd & nd & nd & - \\
\hline 9 & 5.21 & $<1.00$ & $<1.00$ & $<1.00$ & $<1.00$ & $<1.00$ & $<1.00$ & 4.56 & 5.08 & - & 709 & 1593 & 2230 & 37 \\
\hline 10 & 5.20 & $<1.00$ & $<1.00$ & $<1.00$ & $<1.00$ & $<1.00$ & $<1.00$ & $<1.00$ & $<1.00$ & - & nd & nd & nd & - \\
\hline 11 & 5.24 & $<1.00$ & $<1.00$ & $<1.00$ & $<1.00$ & 2.00 & 2.00 & 2.00 & 2.30 & - & nd & nd & nd & - \\
\hline 12 & 5.05 & $<1.00$ & $<1.00$ & $<1.00$ & $<1.00$ & 2.70 & 2.70 & 1.00 & 1.00 & - & nd & nd & nd & - \\
\hline 13 & 5.20 & 5.15 & 5.68 & 6.38 & 6.64 & 7.06 & 6.72 & 6.51 & 6.64 & 4 & 2516 & 3256 & 4935 & 82 \\
\hline 14 & 5.06 & 4.20 & $<1.00$ & $<1.00$ & $<1.00$ & $<1.00$ & $<1.00$ & $<1.00$ & $<1.00$ & - & nd & nd & nd & - \\
\hline $15(\mathrm{C})$ & 5.09 & 4.08 & 2.60 & $<1.00$ & $<1.00$ & 1.70 & 1.70 & $<1.00$ & $<1.00$ & - & nd & nd & nd & - \\
\hline $16(\mathrm{C})$ & 5.15 & 3.60 & 2.60 & $<1.00$ & $<1.00$ & 1.40 & 1.40 & $<1.00$ & $<1.00$ & - & nd & nd & nd & - \\
\hline $17(\mathrm{C})$ & 5.11 & 3.90 & 2.60 & $<1.00$ & $<1.00$ & 1.34 & 1.34 & $<1.00$ & $<1.00$ & - & nd & nd & nd & - \\
\hline
\end{tabular}

a Not detected.

Table 3

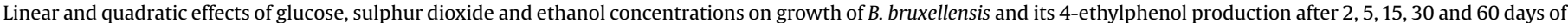
incubation.

\begin{tabular}{|c|c|c|c|c|c|c|c|c|c|c|c|c|c|c|}
\hline \multirow[t]{3}{*}{ Factor } & \multicolumn{10}{|c|}{ Growth } & \multicolumn{4}{|c|}{ 4-Ethylphenol } \\
\hline & \multicolumn{2}{|l|}{$\mathrm{D} 2$} & \multicolumn{2}{|l|}{ D5 } & \multicolumn{2}{|l|}{ D15 } & \multicolumn{2}{|l|}{ D30 } & \multicolumn{2}{|l|}{ D60 } & \multicolumn{2}{|l|}{ D30 } & \multicolumn{2}{|l|}{ D60 } \\
\hline & Effect & $\mathrm{p}$ & Effect & $\mathrm{p}$ & Effect & $\mathrm{p}$ & Effect & $\mathrm{p}$ & Effect & $\mathrm{p}$ & Effect & $\mathrm{p}$ & Effect & $\mathrm{p}$ \\
\hline (1)Glucose (L) & 0 & 1 & 0.13 & 0.81 & 0.01 & 0.98 & -0.93 & 0.27 & -0.99 & 0.13 & -308 & 0.20 & -652 & 0.20 \\
\hline Glucose (Q) & -0.42 & 0.60 & 0.61 & 0.35 & 0.20 & 0.75 & 1.86 & 0.07 & 1.67 & 0.04 & 615 & 0.04 & 40 & 0.04 \\
\hline (2)Ethanol (L) & -0.43 & 0.55 & -0.20 & 0.73 & 0.33 & 0.58 & -1.03 & 0.22 & -0.22 & 0.72 & 221 & 0.35 & -249 & 0.35 \\
\hline Ethanol (Q) & -0.42 & 0.59 & 0.59 & 0.35 & 1.15 & 0.10 & 0.00 & 1.00 & 0.66 & 0.34 & 40 & 0.87 & -358 & 0.87 \\
\hline (3)Sulphur dioxide (L) & -3.89 & 0.00 & -4.15 & 0.00 & -4.54 & 0.00 & -4.43 & 0.00 & -4.25 & 0.00 & -1936 & 0.00 & -2064 & 0.00 \\
\hline Sulphur dioxide $(\mathrm{Q})$ & 1.27 & 0.14 & 2.64 & 0.00 & 2.26 & 0.01 & 2.56 & 0.02 & 2.24 & 0.01 & 1213 & 0.00 & 527 & 0.00 \\
\hline $1 \mathrm{~L}$ by $2 \mathrm{~L}$ & 0 & 1 & 0.08 & 0.91 & 0.18 & 0.82 & -0.01 & 0.99 & -0.01 & 0.99 & 83 & 0.78 & -555 & 0.78 \\
\hline $1 \mathrm{~L}$ by $3 \mathrm{~L}$ & 0 & 1 & -0.23 & 0.76 & -0.02 & 0.97 & 0.10 & 0.92 & -0.02 & 0.98 & -142 & 0.64 & -623 & 0.64 \\
\hline $2 \mathrm{~L}$ by $3 \mathrm{~L}$ & 0.74 & 0.436 & 0.34 & 0.65 & -0.26 & 0.73 & 0.25 & 0.81 & -0.18 & 0.82 & -378 & 0.23 & -841 & 0.23 \\
\hline
\end{tabular}

Fig. 1). This observation may be an indication of the yeast entering the so-called physiological state of "viable-but-not culturable" or VBNC, characterized by inability of the cells to divide on culture media, even though they are still alive and maintain their metabolic or cellular activity (Millet and Lonvaud-Funel, 2000). Sulphur dioxide has been shown to induce the state of VBNC in the wine spoilage yeast Brettanomyces (Agnolucci et al., 2010; Du Toit et al., 2005; Serpaggi et al., 2012). Serpaggi et al. (2012) reported the capability of several strains of $B$. bruxellensis to enter the VBNC state after a sulphite treatment ranging from 0.3 to $1.0 \mathrm{mg} \mathrm{L}^{-1}$ molecular $\mathrm{SO}_{2}$. These authors have observed that removal of $\mathrm{SO}_{2}$ from the environment by increase in extracellular $\mathrm{pH}$, triggering the exit from VBNC in B. bruxellensis. Interestingly, we observed gradual decrease in free sulphur dioxide concentration in the course of time that can explain the recovery of culturability (Supplementary Fig. 1). The ability of these VBNC cells to produce 4-EP was observed in experiment 9 where $709 \mu \mathrm{g} \mathrm{L}{ }^{-1} 4$-EP was detected on day 15 , in the absence of detectable culturable cells (Table 2). However, the amount produced 4-EP was less than that obtained with culturable cells. The production of 4-ethylphenol in experiment 9 after day 15 proceeded at rates similar to those observed with culturable cells during all experiments (see Fig. 1 and Table 2).

Concerning the effect of ethanol, no significant effect on cell death was noticed in initial days of incubation though observations

Table 4

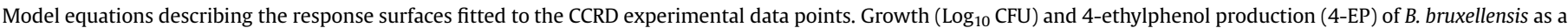
function of the concentration of glucose $(\mathrm{G})$, ethanol (E) and sulphur dioxide (S) and respective $R^{2}$ and $R^{2}$ adj.

\begin{tabular}{|c|c|c|c|}
\hline Parameter & Model equation $^{\mathrm{a}}$ & $R^{2}$ & $R^{2}$-adj \\
\hline $\log _{10}$ CFU 2 days & $7.34-0.365(S)+0.005(S)^{2}$ & 0.81 & 0.78 \\
\hline $\log _{10}$ CFU 5 days & $8.235-0.502(S)+0.0082(S)^{2}$ & 0.89 & 0.88 \\
\hline $\log _{10}$ CFU 15 days & $7.740+0.005(\mathrm{E})-0.461(\mathrm{~S})+0.0068(\mathrm{~S})^{2}$ & 0.88 & 0.85 \\
\hline $\log _{10}$ CFU 30 days & $15.38-1.69(\mathrm{G})+0.125(\mathrm{G})^{2}-0.132(\mathrm{E})-0.482(\mathrm{~S})+0.0074(\mathrm{~S})^{2}$ & 0.87 & 0.81 \\
\hline $\log _{10}$ CFU 60 days & $0.966-0.99(\mathrm{G})+1.63(\mathrm{G})^{2}-0.658(\mathrm{E})^{2}-4.24(\mathrm{~S})+2.24(\mathrm{~S})^{2}$ & 0.91 & 0.87 \\
\hline 4-EP 30 days & $2324-259(\mathrm{Glu})+23.93(\mathrm{G})^{2}+69.1(\mathrm{E})-142.98(\mathrm{~S})+3.25(\mathrm{~S})^{2}-2.34(\mathrm{G} * \mathrm{~S})-2.55(\mathrm{E} * \mathrm{~S})$ & 0.97 & 0.94 \\
\hline 4-EP 30 days & $1991-692(\mathrm{G})+52.34(\mathrm{G})^{2}+286.2(\mathrm{E})-115.15(\mathrm{~S})+4.17(\mathrm{~S})^{2}-10.59\left(\mathrm{E}^{*} \mathrm{~S}\right)$ & 0.94 & 0.90 \\
\hline 4-EP 60 days & $3550-1092(\mathrm{G})+83.03(\mathrm{G})^{2}+442.2(\mathrm{E})-200.4(\mathrm{~S})+6.7(\mathrm{~S})^{2}-16.36(\mathrm{E} * \mathrm{~S})$ & 0.94 & 0.90 \\
\hline
\end{tabular}

a Variables: G ( $\left.\mathrm{g} \mathrm{L}^{-1}\right) ; \mathrm{E}(\% \mathrm{v} / \mathrm{v}) ; \mathrm{S}\left(\mathrm{mg} \mathrm{L}^{-1}\right)$. 

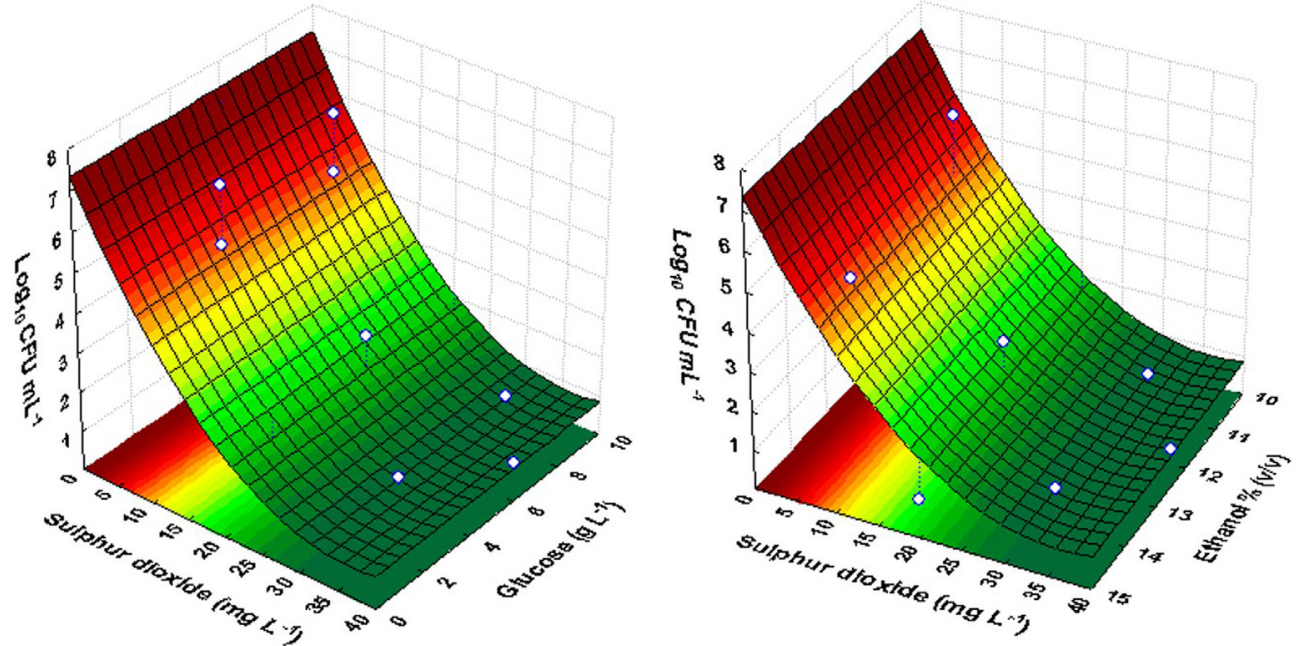

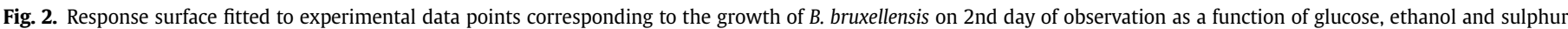
dioxide, in red wine CCRD experiments.
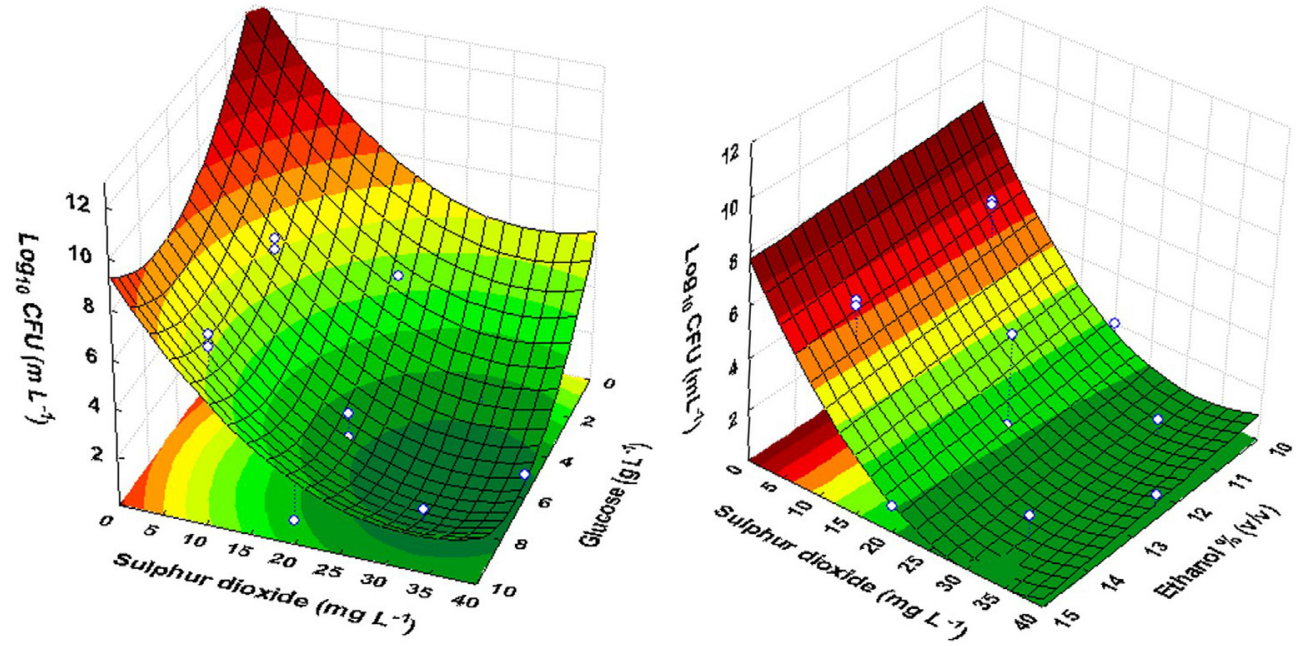

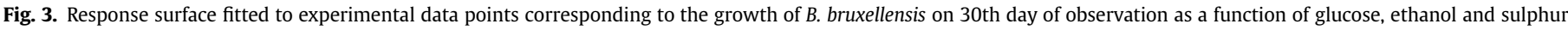
dioxide, on 30th day after inoculation in red wine CCRD experiments.
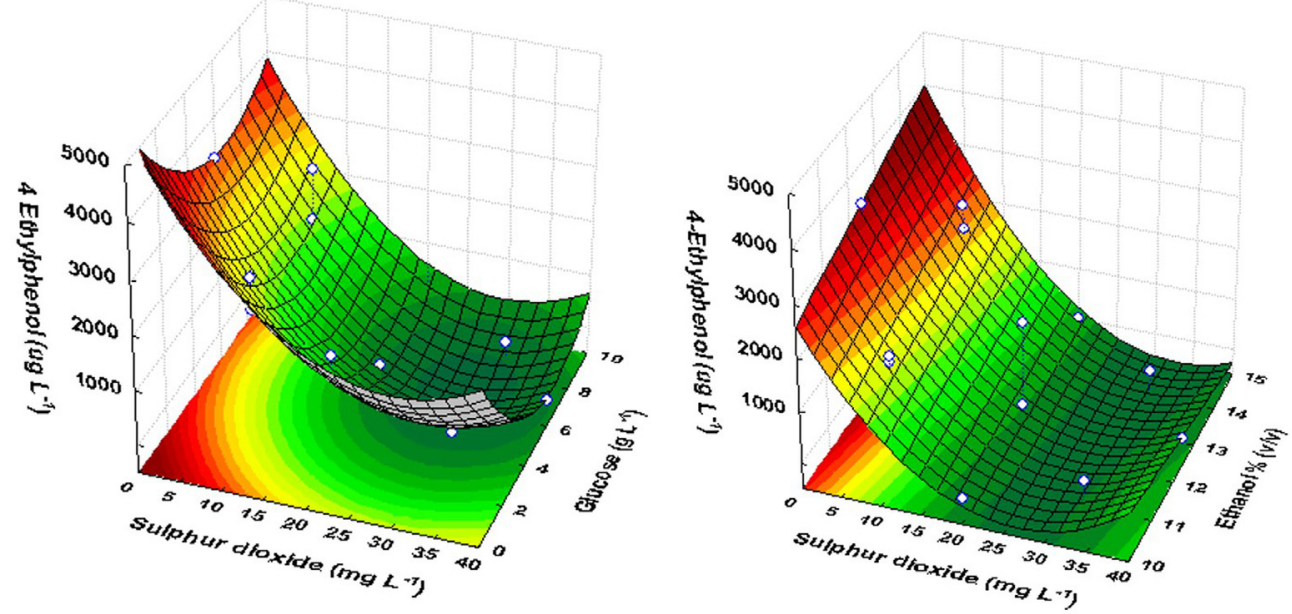

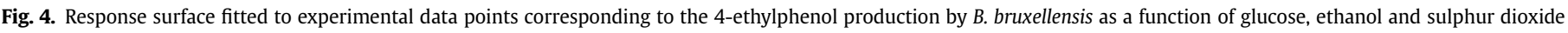
concentrations on 30th day after inoculation in red wine CCRD experiments. 
on day 30 revealed its negative linear effect, when free sulphur dioxide was null (Table 4). Higher concentrations of ethanol caused a delay in lag phase (Table 2). It was observed that the lag phase increased from 3 days under lower ethanol levels (11\% and $12.5 \% \mathrm{v} /$ v) to 10 days under higher i.e., $14 \%(\mathrm{v} / \mathrm{v})$. In the case of the highest ethanol exposure $(15 \% \mathrm{v} / \mathrm{v})$, cells showed low culturable counts, close to the detection limit (experiment 12), and did not produce measurable amounts of 4-EP. Lack of 4-EP production in the presence of growing cells may be explained by the observations of Benito et al. (2009), where cessation of the two key enzymes (phenolic acid decarboxylase and vinyl phenol reductase) for cinnamic acid conversion into 4-EP at high ethanol concentration, has been reported.

With respect to glucose, a quadratic positive effect on growth as well on 4-EP production was noticed only at days 30 and 60 (Table 3). These results may be explained by the absence of free sulphite after these periods of time enabling growth (see Supplementary Fig. 1). Thus a concave response surface may be fitted to the experimental results, as a function of initial glucose concentration (Figs. 2-4). Also, a slightly higher 4-EP production was observed under higher glucose concentrations, as revealed by experiments 2 and $4\left(8.4 \mathrm{~g} \mathrm{~L}^{-1}\right)$ when compared to experiments 1 and $3\left(3.6 \mathrm{~g} \mathrm{~L}^{-1}\right)$, keeping the other factors constant (Table 2). However, higher glucose concentrations (experiment 10) did not induce the recovery from the VBNC state, as observed in experiment 9 . This can be explained by lower susceptibility to death activation by ethanol in the absence of glucose as described by Silva et al. (2004). Overall, our hypothesis is that the glucose is not able to prevent cell death induced either by ethanol or sulphite, but when cells have the ability to grow, higher glucose leads to higher biomass yields and consequent higher 4-EP production, as previously reported by us (Barata et al., 2008).

Besides producing 4-EP, D. bruxellensis has the ability to spoil wine by other activities. Several parameters concerned with wine quality were analysed in the experiments showing high D. bruxellensis growth (Table 5). We observed a 2-4 fold increase in volatile acidity and acetic acid concentration from 30 to 60 days of incubation. Acetic acid production under high glucose concentration has been reported (Hernâni et al., 2000; Suárez et al., 2007) but there was no remarkable difference in the produced acetic acid quantity between high glucose and low glucose concentrations. No major changes were observed in the concentrations of lactic, succinic, tartaric, galacturonic acids and glycerol (data not shown). In addition, up to $30 \%$ loss in the colour depth (CI) and red brilliance ( $\mathrm{dA} \%$ ), and $1 / 3$ fold increase in hue $(\mathrm{T})$ was noticed in spoilt wines compared to unspoiled (control) one (Table 5). Some reports show glycosidic activity ( $\beta$-glucosidase) among Brettanomyces/Brettanomyces strains (Fia et al., 2005; Fugelsang et al., 1993; Mansfield et al., 2002). As a large part of the total glycoside concentration of grapes comprise mono-glucosylated anthocyanins, a primary red pigment in Vitis vinifera (Somers and Vérette, 1988), the hydrolysis of glucose by the action of $\beta$-glucosidase results into the formation of a corresponding anthocyanin. This anthocyanin can be converted

Table 5

Effect of B. bruxellensis spoilage on wine colour and volatile acidity after 60 days of incubation. Wines of CCRD experiments 1, 2, 3 and 4 are considered as spoilt after 60 days of incubation.

\begin{tabular}{llllll}
\hline Wine & $\begin{array}{l}\text { Depth of } \\
\text { colour }(\mathrm{Cl})\end{array}$ & $\begin{array}{l}\text { Hue } \\
(\mathrm{T})\end{array}$ & $\begin{array}{l}\text { Red brilliance } \\
(\mathrm{dA} \%)\end{array}$ & $\begin{array}{l}\text { Volatile acidity } \\
\left(\mathrm{g} \mathrm{L}^{-1}\right)\end{array}$ & $\begin{array}{l}\text { Acetic acid } \\
\left(\mathrm{g} \mathrm{L}^{-1}\right)\end{array}$ \\
\hline Experiment-1 & 0.57 & 1.01 & 37.3 & 1.33 & 1.03 \\
Experiment-2 & 0.62 & 1.06 & 34.8 & 1.42 & 1.18 \\
Experiment-3 & 0.72 & 1.05 & 35.9 & 1.31 & 0.98 \\
Experiment-4 & 0.72 & 1.05 & 35.9 & 1.56 & 1.20 \\
Control & 1.03 & 0.74 & 57.9 & 0.65 & 0.39 \\
\hline
\end{tabular}

into a colourless pseudobase, which consequently affects the colour negatively (Mansfield et al., 2002). This may be the reason of the undesirable colour change in wines heavily contaminated by D. bruxellensis.

\section{Conclusions}

The RSM approach was aimed at explaining the behaviour of $D$. bruxellensis growth and 4-EP as affected by sulphur dioxide, ethanol and glucose. During the period of 30 days where free sulphur dioxide was detected, different responses were observed in growth and production of 4-EP. The most significative linear negative response was induced by sulphur dioxide on cell culturability and 4-EP production within the first 2-15 days of incubation. The inhibitory effect of ethanol was linear, although only observed on day 30 , when free sulphite was null. Furthermore, the effect of ethanol was mostly reflected by an increase in the duration of lag phase. No interactions between glucose, sulphur dioxide or ethanol were observed on growth. However, a negative interaction of sulphur dioxide with ethanol was noticed on 4-EP production at the 30th day of observation. Though glucose, under permissive growth conditions, increased cell numbers and 4-EP production, it could not alleviate the lethal effect of ethanol and sulphur dioxide. As far as we are aware, this is the first report showing that low levels of glucose, used in red wines to give a softer mouthfeel, do not always increase wine susceptibility to spoilage, contrarily to anecdotal belief.

\section{Acknowledgements}

Authors wish to thank FCT (Fundação para a Ciência e a Tecnologia, Ministério da Ciência, Tecnologia e Ensino Superior) for financial support for the project PTDC/AGR-ALI/113565/2009 and for the post-doc (M. Chandra) grant SFRH/BPD/70888/2010.

\section{Appendix A. Supplementary data}

Supplementary data related to this article can be found at http:// dx.doi.org/10.1016/j.fm.2014.03.002.

\section{References}

Agnolucci, M., Rea, F., Sbrana, C., Cristani, C., Fracassetti, D., Tirelli, A., Nuti, M., 2010. Sulphur dioxide affects culturability and volatile phenol production by Brettanomyces/Dekkera bruxellensis. Int. J. Food Microbiol. 143, 76-80.

Barata, A., Caldeira, J., Botelheiro, R., Pagliara, D., Malfeito-Ferreira, M., Loureiro, V., 2008. Survival patterns of Dekkera bruxellensis in wines and inhibitory effect of sulphur dioxide. Int. J. Food Microbiol. 121, 201-207.

Benito, S., Palomero, F., Morata, A., Calderón, F., Suárez-Lepe, J.A., 2009. Factors affecting the hydroxycinnamate decarboxylase/vinylphenol reductase activity of Dekkera/Brettanomyces: application for Dekkera/Brettanomyces control in red wine making. J. Food Sci. 74, M15-M22.

Bertrand, A., 1981. Formation des substances volatiles au cour de la fermentation alcoolique. Incidence sur la qualité du vin. In: Séances du Colloque Societé Française de Microbiologie, pp. 251-267. Reims.

Blouin, J., 1992. In: Salleron, Dujardin (Ed.), Technique d'analyses des moûts et des vins. París.

Chatonnet, P., Dubourdie, D., Boidron, J.-n., Pons, M., 1992. The origin of ethylphenols in wines. J. Sci. Food Agric. 60, 165-178.

Chatonnet, P., Dubourdieu, D., Boidron, J.N., 1995. The influence of Brettanomyces/ Dekkera sp. yeasts and lactic acid bacteria on the ethylphenol content of red wines. Am. J. Enol. Vitic. 46, 463-468.

Ciani, M., Maccarelli, F., Fatichenti, F., 2003. Growth and fermentation behaviour of Brettanomyces/Dekkera yeasts under different conditions of aerobiosis. World J. Microbiol. Biotechnol. 19, 419-422.

Conterno, L., Joseph, C.M.L., Arvik, T.J., Henick-Kling, T., Bisson, L.F., 2006. Genetic and physiological characterization of Brettanomyces bruxellensis strains isolated from wines. Am. J. Enol. Vitic. 57, 139-147.

Coulon, J., Perello, M.C., Lonvaud-Funel, A., De Revel, G., Renouf, V., 2010. Brettanomyces bruxellensis evolution and volatile phenols production in red wines during storage in bottles. J. Appl. Microbiol. 108, 1450-1458. 
Dias, L., Pereira-da-Silva, S., Tavares, M., Malfeito-Ferreira, M., Loureiro, V., 2003. Factors affecting the production of 4-ethylphenol by the yeast Dekkera bruxellensis in enological conditions. Food Microbiol. 20, 377-384.

Du Toit, W.J., Pretorius, I.S., Lonvaud-Funel, A., 2005. The effect of sulphur dioxide and oxygen on the viability and culturability of a strain of Acetobacter pasteurianus and a strain of Brettanomyces bruxellensis isolated from wine. J. Appl. Microbiol. 98, 862-871.

Egli, C.M., Edinger, W.D., Mitrakul, C.M., Henick-Kling, T., 1998. Dynamics of indigenous and inoculated yeast populations and their effect on the sensory character of Riesling and Chardonnay wines. J. Appl. Microbiol. 85, 779-789.

Fia, G., Giovani, G., Rosi, I., 2005. Study of $\beta$-glucosidase production by wine-related yeasts during alcoholic fermentation. A new rapid fluorimetric method to determine enzymatic activity. J. Appl. Microbiol. 99, 509-517.

Froudière, I., Larue, F., 1988. Condition de survie de Brettanomyces (Dekkera) dans le mout de raisin et le vin. Connaiss. Vigne Vin 2, 296-303.

Fugelsang, K.C., Osborn, M.M., Muller, C.J., 1993. Brettanomyces and Dekkera: implications in winemaking. In: Gump, B.H. (Ed.), Beer and Wine Production: Analysis, Characterization and Technological Advances. American Chemical Society, Washington DC, pp. 110-131.

Gacula, J., Singh, J., 1984. Response surface designs and analysis. Academic Press, New York.

Gerbaux, V., Vincent, B., Bertrand, A., 2002. Influence of maceration temperature and enzymes on the content of volatile phenols in Pinot noir wines. Am. J. Enol. Vitic. 53, 131-137.

Heresztyn, T., 1986. Metabolism of volatile phenolic compounds from hydroxycinnamic acids by Brettanomyces yeast. Arch. Microbiol. 146, 96-98.

Hernâni, G., Maria, M.A., Fernanda, C., 2000. Biochemical studies on the production of acetic acid by the yeast Dekkera anomala. Food Technol. Biotechnol. 38, 5962.

Loureiro, V., Malfeito-Ferreira, M., 2006. Spoilage activities of Dekkera/Brettanomyces spp. In: Blackburn, C. (Ed.), Food Spoilage Microorganisms. Woodhead Publishing Limited, Cambridge, England, pp. 354-398.

Malfeito-Ferreira, M., 2011. Yeasts and wine off-flavours: a technological perspective. Ann. Microbiol. 61, 95-102.
Malfeito-Ferreira, M., Barata, A., Nobre, A., Tavares, M., Dias, L., Pereira-da-Silva, S. Gonçalves, G., Rodrigues, N., Loureiro, V., 2004. Behavior of Brettanomyces bruxellensis and Pichia guilliermondii in wines. In: ASEV 55th Annual Meeting, San Diego, California, p. 31.

Mansfield, A.K., Zoecklein, B.W., Whiton, R.S., 2002. Quantification of glycosidase activity in selected strains of Brettanomyces bruxellensis and Oenococcus oeni. Am. J. Enol. Vitic. 53, 303-307.

Millet, V., Lonvaud-Funel, A., 2000. The viable but non-culturable state of wine micro-organisms during storage. Lett. Appl. Microbiol. 30, 136-141.

Montgomery, D.C., 1991. Design and Analysis of Experiments. Wiley, New York p. 649.

Ribéreau-Gayon, P., Dubourdieu, D., Doneche, B., 1998. Traité d'oenologie. In: Chimie du vin. Stabilisation et traitements, sixth éd., Tome 2

Ribéreau-Gayon, P., Glories, Y., Maujean, A., Dubourdieu, D., 2006. Handbook of Enology, Handbook of Enology, second ed. Wiley and Sons Ltd, West Sussex England, pp. 193-216.

Serpaggi, V., Remize, F., Recorbet, G., Gaudot-Dumas, E., Sequeira-Le Grand, A., Alexandre, H., 2012. Characterization of the "viable but nonculturable" (VBNC) state in the wine spoilage yeast Brettanomyces. Food Microbiol. 30, 438-447.

Silva, P., Cardoso, H., Gerós, H., 2004. Studies on the wine spoilage capacity of Brettanomyces/Dekkera spp. Am. J. Enol. Vitic. 55, 65-72.

Somers, T.C., Vérette, E., 1988. Phenolic composition of natural wine types. In: Linskens, H.-F., Jackson, J. (Eds.), Wine Analysis. Springer, Berlin Heidelberg, pp. 219-257.

Suárez, R., Suárez-Lepe, J.A., Morata, A., Calderón, F., 2007. The production of ethylphenols in wine by yeasts of the genera Brettanomyces and Dekkera: a review. Food Chem. 102, 10-21.

Vigentini, I., Joseph, L., Picozzi, C., Foschino, R., Bisson, L.F., 2013. Assessment of the Brettanomyces bruxellensis metabolome during sulphur dioxide exposure. Fems Yeast Res. 13, 597-608.

Vin, O.I.d.I.V. (Ed.), 1990. Recueil des méthodes internationales d'analyse des vins et des moûts. O.I.V, París, p. 368.

Vin, O.I.d.l.V. (Ed.), 2006. Recueil International des Methodes d'Analyses des Vins et des Moutes, p. 2.

Weisberg, S., 1985. Applied Linear Regression, second ed. Wiley, New York, NY. 